\title{
Pengaruh media pembelajaran dan komunikasi interpersonal guru terhadap minat belajar siswa pada mata pelajaran kearsipan di SMKN 1 Bandung
}

\author{
(The influence of instructional media and teacher interpersonal \\ communication on students' learning interest in archival subjects in \\ Bandung)
}

\author{
Febri Rachmawati', Janah Sojanah ${ }^{2 *}$ \\ ${ }^{1,2}$ Program Studi Pendidikan Manajemen Perkantoran, \\ Fakultas Pendidikan Ekonomi dan Bisnis, Universitas Pendidikan Indonesia \\ JI. Dr. Setiabudhi, No. 229 Bandung, Jawa Barat Indonesia \\ Email: janahsojanah@upi.edu
}

\begin{abstract}
ABSTRAK
Permasalahan yang menjadi kajian dalam penelitian ini adalah belum optimalnya minat belajar siswa terhadap Mata Pelajaran Kearsipan. Fokus kajiannya pada faktor-faktor yang mempengaruhi minat belajar siswa dimana media pembelajaran dan komunikasi interpersonal guru merupakan faktor yang diduga memiliki pengaruh terhadap minat belajar siswa. Oleh karena itu, penelitian ini mengkaji tiga variabel yaitu Media Pembelajaran $\left(\mathrm{X}_{1}\right)$, Komunikasi Interpersonal Guru (X2), dan Minat Belajar Siswa (Y). Tujuan penelitian ini untuk mengetahui apakah ada pengaruh dari media pembelajaran dan komunikasi interpersonal guru terhadap minat belajar siswa di SMKN 1 Bandung. Penelitian ini menggunakan metode survey eksplanatory. Teknik pengumpulan data menggunakan angket dengan model skala likert. Responden sebanyak 103 siswa Kelas X Jurusan Administrasi Perkantoran di SMKN 1 Bandung. Teknik analisis menggunakan analisis regresi sederhana dan analisis regresi ganda. Berdasarkan hasil penelitian, diperoleh informasi bahwa media pembelajaran berada pada kategori tinggi, komunikasi interpersonal guru berada pada kategori sedang, sedangkan minat belajar siswa berada pada kategori tinggi. Dari hasil uji hipotesis menunjukkan bahwa media pembelajaran dan komunikasi interpersonal guru berpengaruh positif dan signifikan terhadap minat belajar siswa pada Mata Pelajaran Kearsipan di SMKN 1 Bandung.
\end{abstract}

Kata Kunci: Media Pembelajaran; Komunikasi Interpersonal Guru; Minat Belajar Siswa

ABSTRACT
The problem arising in the study was the lack of student learning interest in
Archival subject. The focus of research relied on the factors affecting student
learning interest where learning instrument and teacher interpersonal

Received: Februari 2019, Revision: Mei 2019, Published: Juli 2019

*Corresponding author

Copyright @ 2019, EISSN 2656- 4734 
communication were the anticipated factors which have impact on student learning interest. Focusing on that, we would study three variables namely Learning Instrument $\left(X_{1}\right)$, Teacher Interpersonal Communication $\left(X_{2}\right)$, and Student Learning Interest $(Y)$. The aim of the study was to obtain information regarding the influence of learning instrument and teacher interpersonal communication on student learning interest in SMKN 1 Bandung. Current research employed explanatory survey method, whilst data collection employed questionnaire with likert scale model. Involved respondents were 103 junior students majoring in Office Administration in SMKN 1 Bandung. Analysis technique used single and double regression analysis. Research findings revealed that learning instrument is at the uppermost category, teacher interpersonal communication is at the average category, and student learning interest at the uppermost category. Results showed that learning instrument and teacher interpersonal communication have positive and significant impact on student learning interest in Archival subject in SMKN 1 Bandung.

Keyword: Learning Instrument; Teacher Interpersonal Communication; Student Learning Interest

\section{PENDAHULUAN}

Minat belajar siswa menjadi salah satu masalah penting utnuk dikaji di dalam dunia pendidikan karena minat belajar mempengaruhi prestasi belajar siswa. Siswa yang memiliki minat belajar yang tinggi akan merasa bahwa belajar merupakan kegiatan yang menyenangkan sehingga akan berpotensi untuk mencapai keberhasilan belajar. Pada proses pembelajaran, minat merupakan salah satu faktor internal siswa yang sangat penting dalam membantu tercapainya tujuan pembelajaran.

Pada saat ini, gejala yang terjadi di lapangan menunjukkan rendahnya minat belajar siswa dilihat dari tingkat ketidakhadiran siswa dan nilai siswa serta rekapitulasi penilaian keaktifan siswa yang masih jauh dari harapan.

Seperti yang dikemukakan oleh Dalyono dalam Djamarah (2011, hlm. 157) mengemukakan bahwa "Minat belajar yang besar cenderung menghasilkan prestasi yang tinggi, sebaliknya minat belajar yang kurang akan menghasilkan prestasi yang rendah".

Djamarah (2011, hlm. 166) mengemukakan bahwa "Minat tidak hanya diekspresikan melalui pernyataan yang menunjukkan bahwa anak didik lebih menyukai sesuatu daripada yang lainnya, tetapi juga mengimplementasikannya melalui partisipasi aktif dalam suatu kegiatan". Berdasarkan pernyataan tersebut bahwa apabila siswa mempunyai minat belajar yang tinggi, maka selain siswa menunjukkan rasa suka, siswa juga mengimplementasikannya melalui partisipasi aktif salah satunya dilihat dari tingkat kehadiran siswa.

Hasil studi awal menunjukkan bahwa minat belajar siswa pada Mata Pelajaran Kearsipan masih belum optimal. Hal ini ditunjukkan dengan tingkat ketidakhadiran siswa. Data menunjukkan bahwa pada Tahun Ajaran 2011/2012, tingkat rata-rata ketidakhadiran siswa 2,53\%, kemudian untuk Tahun Ajaran 2012/2013 menunjukkan adanya penurunan jumlah rata-rata ketidakhadiran siswa sebesar $0,2 \%$ menjadi $2,33 \%$. Untuk Tahun Ajaran 2013/2014, rata-rata ketidakhadiran siswa sebesar 2,19\% yang 
menunjukkan bahwa rata-rata ketidakhadiran siswa menurun sebesar $0,14 \%$ dari tahun pelajaran sebelumnya. Pada Tahun Ajaran 2014/2015, jumlah rata-rata ketidakhadiran siswa mengalami penurunan yang cukup besar yaitu $1 \%$ menjadi $1,19 \%$. Sementara itu, Tahun Ajaran 2015/2016 rata-rata ketidakhadiran siswa mengalami kenaikan sebesar $0,62 \%$ menjadi $1,81 \%$. Rata-rata ketidakhadiran siswa dari tahun ke tahun menjadi salah satu bukti bahwa masih belum optimalnya minat siswa yang terlihat dari ketidakhadiran siswa, ini terlihat dari fluktuatif tingkat ketidakhadiran siswa tanpa keterangan (alpha) yang masih mengalami kenaikan dan penurunan. Penjelasan tersebut menunjukkan bahwa kenaikan ketidakhadiran siswa tertinggi terjadi dari Tahun Ajaran 2014/2015 ke Tahun Ajaran 2015/2016 dengan kenaikan sebesar 0,62\% sedangkan pada tahun-tahun sebelumnya jumlah rata-rata ketidakhadiran siswa mengalami penurunan.

Selain data tingkat kehadiran tersebut, ada pula data bahwa masih banyak siswa yang Nilai Ujian Akhir Semester belum memenuhi KKM. Pada Tahun Ajaran 2011/2012, persentase rata-rata siswa yang nilainya belum memenuhi KKM sebesar 18,17\% dan mengalami penurunan Pada tahun Ajaran 2012/2013 sebesar 2,71\% menjadi 15,46\%. Sedangkan di Tahun Ajaran 2013/2014, jumlah rata-rata siswa yang nilainya belum memenuhi KKM sebesar $24,64 \%$ dan menunjukkan bahwa adanya kenaikan sebesar 9,18\%. Pada Tahun Ajaran 2014/2015 mengalami penurunan rata-rata siswa yang belum memenuhi KKM yang cukup besar yaitu 15,6\% menjadi 9,04\% . Sementara itu, pada Tahun Ajaran 2015/2016 rata-rata nilai siswa yang belum memenuhi KKM sebesar 12,76\% dan mengalami kenaikan sebesar 3,72\%.

Pernyataan tersebut menunjukkan bahwa siswa yang mendapatkan nilai kurang dari KKM pada Mata Pelajaran Kearsipan tertinggi ada di Tahun Ajaran 2012/2013 yaitu sebesar $24,64 \%$ dan kenaikan tertinggi siswa yang mendapatkan nilai kurang dari KKM ada di tahun ajaran 2012/2013 ke Tahun Ajaran 2013/2014 yaitu sebesar 9,18\%.

Mengingat pentingnya meningkatkan minat belajar siswa untuk dapat mencapai tujuan pembelajaran yang diharapkan. Apabila hal tersebut tidak cepat di atasi, maka akan berakibat pada tujuan pembelajaran yang tidak tercapai.

Salah satu faktor penting dalam membangkitkan minat belajar siswa adalah melalui media pembelajaran dan komunikasi interpersonal guru. Sehingga hal ini membuat guru untuk lebih peka terhadap perubahan perilaku pada diri siswa dan memperhatikan proses pembelajaran yang dapat menimbulkan rasa senang pada diri siswa sehingga dapat mencapai tujuan pembelajaran yang diharapkan. Maka dari itu guru dan pihak sekolah dituntut untuk memenuhi kebutuhan siswa, agar dapat meningkatkan keberhasilan pembelajaran.

\section{TINJAUAN PUSTAKA \\ Media Pembelajaran}

Yusuf Hadi Miarso (2004, hlm. 456) mengemukakan bahwa media pembelajaran adalah segala sesuatu yang digunakan untuk menyalurkan pesan serta dapat merangsang pikiran, perasaan, perhatian, dan kemauan si belajar sehingga dapat mendorong terjadinya proses belajar yang disengaja, bertujuan, dan terkendali.

Commission on Instructional Technology dalam (Miarso, 2004, hlm. 456) mendefinisikan media pembelajaran sebagai media yang lahir akibat adanya revolusi komunikasi yang dapat digunakan untuk tujuan pembelajaran di samping guru, buku teks, dan papan tulis. Sedangkan Gagne dalam (Miarso, 2004, hlm. 456) menyatakan 
bahwa media pembelajaran adalah sarana untuk memberikan rangsangan bagi si pembelajar supaya terjadi proses belajar.

Menurut Anderson (1987) dalam Bambang Warsita (2008, hlm. 123). Media dapat dibagai dalam dua kategori, yaitu alat bantu pembelajaran (instructional aids) dan media pembelajaran (instructional media). Alat bantu pembelajaran atau alat untuk membantu guru (pendidik) dalam memperjelas materi (pesan) yang akan disampaikan.

Nana Sudjana dan Ahmad Rivai (2011, hlm. 79) menyatakan bahwa terdpat lima indikator dalam penggunaan media pembelajaran, yaitu: 1). Relevansi; 2). Kemampuan Guru; 3). Kemudahan Penggunaan; 4). Ketersediaan; dan 5). Kebermanfaatan.

Dari beberapa pendapat ahli di atas mengenai pengertian media pembelajaran, dapat disimpulkan bahwa media pembelajaran merupakan alat atau sarana yang digunakan untuk menyampaikan pesan dari pendidik kepada peserta didik yang dapat merangsang pikiran, perasaan, perhatian dan kemampuan atau keterampilan peserta didik sehingga dapat mendorong terjadinya proses pembelajaran.

\section{Komunikasi Interpersonal}

Wiryanto (2005, hlm. 32) mengemukakan komunikasi interpersonal adalah komunikasi yang berlangsung dalam situasi tatap muka antara dua orang atau lebih baik secara terorganisasi maupun dalam kerumunan orang. Selanjutnya, Wiryanto (2005, hlm. 36) menyatakan bahwa "Pada hakikatnya komunikasi antarpribadi adalah komunikasi antara komunikator dengan komunikan. Komunikasi ini paling efektif mengubah sikap, pendapat, atau perilaku seseorang".

Deddy Mulyana (2009, hlm. 81) mendefinisikan komunikasi antarpribadi (interpersonal communication) adalah komunikasi yang terjadi antara orang-orang secara tatap muka, yang memungkinkan setiap pesertanya menangkap reaksi orang lain secara langsung baik secara verbal maupun non verbal. Bentuk khusus dari komunikasi antarpribadi ini adalah komunikasi diadik (dyadic communication) yang komunikasi melibatkan hanya dua orang, seperti suami-istri, dua sejawat, dua sahabat dekat, gurumurid, pimpinan-bawahan dan sebagainya.

Suranto Aw (2011, hlm.5) mengemukakan pengertian yang sederhana, bahwa komunikasi interpersonal atau komunikasi antarpribadi adalah proses penyampaian dan penerimaan pesan antara pengirim pesan (sender) dengan penerima (receiver) baik secara langsung maupun tidak langsung.

Komunikasi interpersonal yang efektif adalah penting bagi anggota organisasi yang diharapkan dapat membawa hasil pertukaran informasi dan saling pengertian (mutual understanding). Efektivitas komunikasi interpersonal dalam pandangan humanistic menurut Devito dalam Suranto Aw (2011, hlm. 82) mengandung indikator sebagai berikut: 1) Keterbukaan; 2) Empati; 3) Sikap Mendukung; 4) Sikap Positif; 5) Kesetaraan.

Dari beberapa pengertian di atas tentang komunikasi interpersonal menurut para ahli dapat disimpulkan bahwa komunikasi interpersonal adalah proses interaksi yang di lakukan oleh individu kepada individu lain yang mencakup semua aspek komunikasi seperti mendengarkan, membujuk, menegaskan, komunikasi verbal dan nonverbal, dan sebagainya dengan menerima feedback secara maksimal. 


\section{Minat Belajar}

\section{a. Minat}

Menurut W.S Winkel (2007, hlm. 212), "Minat adalah kecenderungan subjek yang menetap untuk merasa tertarik pada bidang studi atau pokok bahasan tertentu dan merasa senang mempelajari materi pelajaran.Hubungannya dalam belajar antara senang dan berperasaan terdapat hubungan timbal balik.Jika siswa merasa senang untuk mempelajari sesuatu maka akan dapat dengan mudah untuk memahami apa yang telah dipelajarinya, sehingga dapat memperoleh prestasi belajar yang menyenangkan”.

Pendapat lainnya menurut Muhibbin Syah (2013, hlm. 152) menyatakaan bahwa "Minat (interest) berarti kecenderungan dan kegairahan yang tinggi atau keinginan yang besar terhadap sesuatu". Lalu pendapat menurut Slameto (2015, hlm. 180), "Minat adalah suatu rasa lebih suka dan rasa ketertarikan pada suatu alat atau aktifitas tanpa ada yang menyuruh".

Mangal (2007) Soenarto (2003) dalam Nurmala (2012, hlm. 165) menyatakan bahwa "Interest may be referred to as the key factor and a driving force that helps us in paying attention as well as remaining enganged in our so attented activities. Our interest are very much linked with our want, motives, drives and basic needs". Keterangan ini menunjukkan bahwa minat berkaitan erat dengan faktor pendorong dalam diri seseorang yang membantu orang tersebut melakukan aktivitas-aktivitas yang sesuai.Minat tersebut sangat berkaitan erat dengan masalah keinginan, motif, dorongan dan kebutuhan-kebutuhan dasar.

Dari beberapa pengertian para ahli di atas maka dapat disimpulkan bahwa minat adalah rasa suka seseorang terhadap sesuatu yang dianggapnya sangat menarik untuk dipelajari lebih lanjut tanpa adanya paksaan dari manapun.Jika siswa merasa senang untuk mempelajari sesuatu maka akan dapat dengan mudah untuk memahami apa yang telah dipelajarinya

\section{b. Minat Belajar}

Lai dalamU-Je Lee (2011, hlm. 142) mendefinisikan bahwa "Minat belajar adalah preferensi pribadi berkaitan dengan pembelajaran, yang kadang-kadang berarti seorang individu memilih satu hal daripada hal-hal lain dan kadang-kadang keadaan psikologis yang positif terjadi selama interaksinya dengan keadaan yang menimbulkan motif belajar lebih lanjut".

Sementara itu, Dalyono (2009, hlm. 57) mengatakan bahwa "Minat belajar yang besar cenderung menghasilkan prestasi yang tinggi. Sebaliknya, minat belajar yang kurang akan menghasilkan prestasi yang rendah"

Menurut Purwanto dalam Hamalik (2009, hlm. 103-104) menjelaskan mengenai faktor-faktor yang mempengaruhi minat yaitu faktor individu atau faktor internal meliputi kematangan/pertumbuhan, latihan, kecerdasan, motivasi, dan pribadi. Faktor sosial atau faktor eksternal terdiri dari faktor keluarga, guru dan metode mengajarnya, lingkungan belajar dan media atau alat-alat yang digunakan dalam belajar mengajar. Menurut Safari dalam Herlina (2010, hlm. 20) mengemukakan indikator minat belajar siswa sebagai berikut: 1) Kesukaan; 2) Ketertarikan; 3) Perhatian; 4) Keterlibatan.

Dari beberapa pengertian menurut para ahli, dapat disimpulkan bahwa minat belajar adalah dorongan yang muncul dari dalam diri seseorang terhadap suatu hal yang dapat dipelajari yang dianggap penting tanpa adanya paksaan untuk mempelajari hal 
tersebut yang diikuti dengan perasaan senang pada dirinya sehingga menciptakan suatu prestasi.

\section{METODOLOGI}

Arikunto (2002, hlm. 136) menjelaskan "Metode penelitian adalah cara yang digunakan oleh peneliti dalam mengumpulkan data penelitiannya". Metode penelitian bertujuan untuk memberikan menggambarkan langkah-langkah penelitian yang dilakukan, sehingga permasalahan yang sedang diteliti dapat dipecahkan.

Metode penelitian yang digunakan dalam penelitian ini adalah metode survey eksplanatori. Menurut Moh. Nazir (2005, hlm. 56) metode survey adalah penyelidikan yang diadakan untuk memperoleh fakta-fakta dari gejala-gejala yang ada dan mencari keterangan-keterangan secara faktual, baik tentang institusi sosial, ekonomi, atau politik dari suatu kelompok ataupun suatu daerah serta menjelaskan hubungan antara dua variabel atau lebih melalui pengajuan hipotesis.

Pada penelitian ini, metode yang digunakan adalah analisis data deskriptif dan inferensial. Analisis data deskriptif yang dilakukan melalui statistika deskriptif, yaitu statistik yang digunakan untuk menganalisis data dengan cara mendeskripsikan atau menggambarkan data yang telah terkumpul sebagaimana adanya tanpa bermaksud membuat generalisasi hasil penelitian (Muhidin \& Sontani, 2011, hlm. 163).

Penelitian deskriptif bertujuan untuk memperoleh gambaran tentang Media Pembelajaran, Komunikasi Interpersonal Guru dan Minat Belajar Siswa pada Mata Pelajaran Kearsipan di SMKN 1 Bandung. Lalu penelitian dekriptif pada dasarnya ingin menguji kebenaran dari suatu hipotesis yang dilaksanakan melalui pengumpulan data dilapangan.

Analisis data inferensial meliputi statistik parametris yang digunakan untuk data interval dan ratio serta statistik nonparametris yang digunakan untuk data nominal dan ordinal. Dalam penelitian ini menggunakan analisis parametris karena data yang digunakan adalah data interval. Ciri analisis data inferensial adalah digunakan rumus statistik tertentu (misalnya uji t, uji F, dan lain sebagainya).

Analisis data ini dilakukan untuk mengetahui adakah pengaruh komunikasi interpersonal guru terhadap minat belajar siswa, juga untuk mengetahui adakah pengaruh media pembelajaran dan komunikasi interpersonal guru terhadap minat belajar siswa. Teknik analisis data inferensial terdiri dari 4 langkah, pertama merumuskan hipotesis statistik, lalu menghitung regresi, koefisien korelasi dan koefisien determinasi.

Metode yang digunakan dalam penelitian ini bertujuan untuk mengumpulkan informasi faktual melalui kuesioner/angket. Model skala likert digunakan dalam penelitian ini dengan rentang 1 sampai 5 dengan jumlah responden penelitian sebanyak 103 orang di salah satu sekolah di kota Bandung. Instrumen pengumpulan data terdiri dari 3 bagian, bagian pertama adalah angket untuk mengukur Media Pembelajaran $\left(\mathrm{X}_{1}\right)$ yang terdiri dari dalam 5 indikator yang terdiri dari indikator: relevansi, kemampuan guru, kemudahan penggunaan, ketersediaan, dan kebermanfaatan. Bagian kedua adalah angket Komunikasi Interpersonal Guru $\left(\mathrm{X}_{2}\right)$ yang terdiri dari indikator: keterbukaan, empati, sikap mendukung, sikap positif, kesetaraan, dan Minat Belajar Siswa (Y) yang terdiri dari indikator: kesukaan, ketertarikan, perhatian, keterlibatan. Sebelum melakukan penyebaran instrumen kepada responden, peneliti melakukan uji coba terlebih dahulu dengan melakukan uji validitas dan uji reliabilitas, instrumen penelitian 
yang digunakan adalah angket. Setelah semua data terkumpul, peneliti melakukan analisis data sehingga dapat memperoleh hasil penelitian.

Gambaran dari tanggapan responden dalam hal media pembelajaran, komunikasi interpersonal dan minat belajar siswa diperoleh dengan statistik deskriptif menggunakan skor rata-rata tiap bagian. Kemudian teknik analisis untuk menguji hipotesis penelitian menggunakan regresi sederhana dan regresi ganda.

\section{HASIL PENELITIAN DAN PEMBAHASAN Media Pembelajaran $\left(\mathbf{X}_{1}\right)$}

Variabel Media Pembelajaran dalam penelitian ini diukur menggunakan lima indikator yaitu, relevansi, kemampuan guru, kemudahan penggunaan, ketersediaan, dan kebermanfaatan. Kelima indikator tersebut diuraikan menjadi 11 pernyataan yang dijadikan ukuran tentang Variabel Media Pembelajaran, berdasarkan perhitungan dari 103 orang responden.

Deskripsi Variabel Media Pembelajaran diperoleh melalui perhitungan frekuensi dan persentase terhadap perolehan data Media Pembelajaran, diperoleh hasil seperti tampak pada Tabel berikut ini:

\section{Tabel 1}

\section{Rekapitulasi Tanggapan Responden terhadap Variabel Media Pembelajaran}

\begin{tabular}{|l|c|c|}
\hline \multicolumn{1}{|c|}{ Indikator } & Rata-rata & Penafsiran \\
\hline Relevansi & 4,09 & Tinggi \\
\hline Kemampuan Guru & 3,67 & Sedang \\
\hline Kemudahan Penggunaan & 3,64 & Sedang \\
\hline Ketersediaan & 3,52 & Sedang \\
\hline Kebermanfaatan & 4,13 & Tinggi \\
\hline \multicolumn{1}{|c|}{ Rata-rata Variabel $\mathbf{X}_{\mathbf{1}}$} & $\mathbf{3 , 8 1}$ & Tinggi \\
\hline
\end{tabular}

Sumber: Skor Hasil Pengolahan Jawaban Responden

Dari Tabel 1 menunjukkan bahwa rata-rata skor jawaban responden untuk Variabel Media Pembelajaran sebesar 3,81. Apabila dihubungkan dengan skala penafsiran pada tabel penafsiran skor rata-rata, maka angka tersebut berada pada rentang 3,80 - 5,10 atau berada pada kategori tinggi.

Pada indikator pertama yaitu Relevansi, skor rata-rata jawaban responden sebesar 4,09 dan berdasarkan skala penafsiran angka tersebut berada pada rentang 3,85,1 atau dalam penafsiran tinggi. Pada indikator kedua yaitu Kemampuan Guru, skor rata-rata jawaban responden sebesar 3,67 dan berdasarkan skala penafsiran angka tersebut berada pada rentang 2,40-3,70 atau dalam penafsiran sedang. Pada indikator ketiga yaitu Kemudahan Penggunaan, skor rata-rata jawaban responden sebesar 3,64 dan berdasarkan skala penafsiran angka tersebut berada pada rentang 2,40-3,70 atau dalam penafsiran sedang. Pada indikator keempat yaitu Ketersediaan, skor rata-rata jawaban responden sebesar 3,52 dan berdasarkan skala penafsiran angka tersebut berada pada rentang 2,40-3,70 atau dalam penafsiran sedang. Pada indikator kelima yaitu Kebermanfaatan skor rata-rata jawaban responden sebesar 3,81 dan berdasarkan skala penafsiran angka tersebut berada pada rentang 3,80-5,10 atau dalam penafsiran tinggi. 
Skor rata-rata jawaban tertinggi Variabel Media Pembelajaran berada pada indikator kebermanfaatan yaitu sebesar 4,13 dan skor rata-rata terendah adalah indikator ketersediaan sebesar 3,52. Pada indikator ketersediaan, fakta yang terjadi di sekolah ditemukan bahwa media pembelajaran yang digunakan pada Mata Pelajaran Kearsipan masih ada yang tidak tersedia dan tidak sesuai dengan jumlah siswa. Berbeda dengan indikator ketersediaan, indikator kebermanfaatan dipersepsikan kuat karena penggunaan media pembelajaran pada Mata Pelajaran Kearsipan sudah bermanfaat dan sesuai dengan kebutuhan belajar siswa meskipun masih ada yang tidak sesuai dengan jumlah siswa. Secara keseluruhan, dapat disimpulkan bahwa media pembelajaran di SMKN 1 Bandung dipersepsikan tinggi.

\section{Komunikasi Interpersonal Guru}

Variabel Komunikasi Interpersonal Guru dalam penelitian ini diukur menggunakan lima indikator yaitu, keterbukaan, empati, sikap mendukung, sikap positif, kesetaraan. Kelima indikator tersebut diuraikan menjadi 11 pernyataan yang dijadikan ukuran tentang Variabel Komunikasi Interpersonal Guru, berdasarkan perhitungan dari 103 orang responden.

Deskripsi Variabel Komunikasi Interpersonal Guru diperoleh melalui perhitungan frekuensi dan persentase terhadap perolehan data komunikasi interpersonal guru. Berdasarkan perhitungan, diperoleh hasil seperti tampak pada Tabel berikut ini:

\section{Tabel 2}

\section{Rekapitulasi Tanggapan Responden terhadap Variabel Komunikasi Interpersonal} Guru

\begin{tabular}{|l|c|c|}
\hline \multicolumn{1}{|c|}{ Indikator } & Rata-rata & Penafsiran \\
\hline Keterbukaan & 3,80 & Tinggi \\
\hline Empati & 3,65 & Sedang \\
\hline Sikap Mendukung & 3,85 & Tinggi \\
\hline Sikap Positif & 3,92 & Tinggi \\
\hline Kesetaraan & 3,50 & Sedang \\
\hline \multicolumn{1}{|c|}{ Rata-rata Variabel $\mathbf{X}_{\mathbf{2}}$} & $\mathbf{3 , 7 4}$ & Sedang \\
\hline
\end{tabular}

Sumber: Skor Hasil Pengolahan Jawaban Responden

$\mathrm{D}$ ari Tabel 2 dapat dilihat bahwa rata-rata skor jawaban responden untuk Variabel Komunikasi Interpersonal Guru sebesar 3,74. Apabila dihubungkan dengan skala penafsiran pada tabel penafsiran skor rata-rata, maka angka tersebut berada pada rentang 2,4 - 3,7 atau berada pada kategori sedang.

Pada indikator pertama yaitu Keterbukaan, skor rata-rata jawaban responden sebesar 3,80 dan berdasarkan skala penafsiran angka tersebut berada pada rentang 3,805,10 atau dalam penafsiran tinggi. Pada indikator kedua yaitu Empati, skor rata-rata jawaban responden sebesar 3,65 dan berdasarkan skala penafsiran angka tersebut berada pada rentang 2,40-3,70 atau dalam penafsiran sedang. Pada indikator ketiga yaitu Sikap Mendukung, skor rata-rata jawaban responden sebesar 3,85 dan berdasarkan skala 
penafsiran angka tersebut berada pada rentang 3,80-5,10 atau dalam penafsiran tinggi. Pada indikator keempat yaitu Sikap Positif, skor rata-rata jawaban responden sebesar 3,92 dan berdasarkan skala penafsiran angka tersebut berada pada rentang 3,80-5,10 atau dalam penafsiran tinggi. Pada indikator kelima yaitu Kesetaraan skor rata-rata jawaban responden sebesar 3,50 dan berdasarkan skala penafsiran angka tersebut berada pada rentang 2,40-3,70 atau dalam penafsiran sedaang.

Skor rata-rata jawaban tertinggi berada pada indicator Sikap Positif yaitu sebesar 3,92 dan skor rata-rata terendah adalah indikator kesetaraan sebesar 3,50. Pada indikator kesetaraan, fakta yang terjadi di sekolah ditemukan bahwa guru belum mengenali seluruh siswa, guru hanya mengenali siswa-siswa yang aktif saja sehingga terkadang guru masih membeda-bedakan siswa. Berbeda dengan indikator kesetaraan, indikator sikap positif dipersepsikan kuat karena fakta yang terjadi di sekolah ditemukan bahwa guru selalu berkomunikasi dengan baik kepada siswa dan komunikasi yang dilakukan oleh guru terhadap siswa akrab, selain itu guru selalu memberi motivasi kepada siswa agar siswa giat belajar. Secara keseluruhan, dapat disimpulkan bahwa komunikasi interpersonal guru di SMKN 1 Bandung dipersepsikan sedang.

\section{Minat Belajar}

Variabel Minat Belajar Siswa dalam penelitian ini diukur menggunakan empat indikator yaitu, kesukaan, ketertarikan, perhatian, keterlibatan. Keempat indikator tersebut diuraikan menjadi 13 pernyataan yang dijadikan ukuran tentang Variabel Minat Belajar Siswa, berdasarkan perhitungan dari 103 orang responden.

Deskripsi Variabel Minat Belajar Siswa diperoleh melalui perhitungan frekuensi dan persentase terhadap perolehan data minat belajar siswa, sebagaimana tercantum pada Tabel 3.

Tabel 3

Rekapitulasi Tanggapan Responden terhadap Variabel Minat Belajar Siswa

\begin{tabular}{|l|c|c|}
\hline \multicolumn{1}{|c|}{ Indikator } & Rata-rata & Penafsiran \\
\hline Kesukaan & 4,06 & Tinggi \\
\hline Ketertarikan & 3,40 & Sedang \\
\hline Perhatian & 4,21 & Tinggi \\
\hline Keterlibatan & 4,01 & Tinggi \\
\hline \multicolumn{1}{|c|}{ Rata-rata Variabel Y } & $\mathbf{3 , 9 2}$ & Tinggi \\
\hline
\end{tabular}

Sumber: Skor Hasil Pengolahan Jawaban Responden

Dari Tabel 3 menyatakan bahwa rata-rata skor jawaban responden untuk Variabel Minat Belajar Siswa sebesar 3,92. Apabila dihubungkan dengan skala penafsiran pada tabel penafsiran skor rata-rata, maka angka tersebut berada pada rentang 3,7 - 5,1 atau berada pada kategori tinggi.

Pada indikator pertama yaitu Ketsukaan, skor rata-rata jawaban responden sebesar 4,06 dan berdasarkan skala penafsiran angka tersebut berada pada rentang 3,805,10 atau dalam penafsiran tinggi. Pada indikator kedua yaitu ketertarikan, skor rata-rata jawaban responden sebesar 3,40 dan berdasarkan skala penafsiran angka tersebut berada pada rentang 2,40-3,70 atau dalam penafsiran sedang. Pada indikator ketiga yaitu Sikap Perhatian, skor rata-rata jawaban responden sebesar 4,21 dan berdasarkan skala 
penafsiran angka tersebut berada pada rentang 3,80-5,10 atau dalam penafsiran tinggi. Pada indikator keempat yaitu Keterlibatan, skor rata-rata jawaban responden sebesar 3,92 dan berdasarkan skala penafsiran angka tersebut berada pada rentang 3,80-5,10 atau dalam penafsiran tinggi.

Skor jawaban tertinggi berada pada indikator perhatian yaitu sebesar 4,21 dan skor rata-rata terendah adalah indikator ketertarikan sebesar 3,40. Pada indikator ketertarikan, fakta yang terjadi di sekolah ditemukan bahwa tidak semua materi yang disampaikan oleh guru membuat siswa tertarik, hanya materi-materi yang menurut siswa mudah saja yang membuat siswa tertarik. Berbeda dengan indikator ketertarikan, indikator perhatian dipersepsikan kuat karena pada saat guru menjelaskan materi Kearsipan siswa memperhatikan dan fokus. Secara keseluruhan, dapat disimpulkan bahwa minat belajar siswa di SMKN 1 Bandung dipersepsikan sedang.

\section{Pengaruh Media Pembelajaran terhadap Minat Belajar Siswa}

Peneliltian ini menggunakan uji statistik dan di dapatkan berdasarkan hasil uji statistik dari data yang telah di kumpulkan dan di olah bahwa data penelitian inni berdistribusi normal, homogen dan linier. Dengan demikian penulis melanjutkan pengujian hipotesis dengan menggunakan statistik parametrik. Pengujian hipotesis yang dilakukan bertujuan untuk membuat suatu kesimpulan bahwa Variabel Media Pembelajaran memiliki pengaruh positif terhadap Variabel Minat Belajar Siswa. Berdasarkan hasil perhitungan hipotesis dari pengolahan data di SPSS 20.0 maka diperoleh $t_{\text {hitung }}>t_{\text {tabel }}$ dengan nilai 3,774 > 1,98397, yang dimana $\mathrm{H}_{0}$ ditolak dan $\mathrm{H}_{1}$ diterima. Dengan kesimpulan bahwa "Terdapat pengaruh positif antara Media Pembelajaran dengan Minat Belajar Siswa pada Mata Pelajaran Kearsipan di SMKN 1 Bandung".

Persamaan regresi linier sederhana untuk hipotesis Variabel Media Pembelajaran $\left(\mathrm{X}_{1}\right)$ terhadap Variabel Minat Belajar Siswa $(\mathrm{Y})$ adalah $\hat{\mathrm{Y}}=30,949+0,498(\mathrm{X})$. Tanda positif (+) menunjukkan hubungan antara variabel bebas dengan variabel terikat berjalan satu arah, yang artinya setiap peningkatan atau penurunan di satu level variabel, akan diikuti oleh peningkatan atau penurunan di satu variabel lainnya, sehingga apabila semakin tinggi tingkat media pembelajaran maka semakin tinggi pula minat belajar siswa, begitupun sebaliknya.

Hasil nilai perhitungan korelasi yang didapat sebesar 0,352 , ini berarti nilai korelasi tersebut berada pada rentang antara 0,200 sampai 0,399 dan berada pada kategori lemah. Hal tersebut mengindikasikan bahwa adanya pengaruh yang lemah dari Variabel Media Pembelajaran $\left(\mathrm{X}_{1}\right)$ terhadap Variabel Minat Belajar Siswa (Y).

Dari perhitungan koefisien determinasi di atas, dapat dilihat bahwa koefisien determinasi ( $\mathrm{R}$ Square $/ \mathrm{r}^{2}$ ) sebesar 0,124 atau jika dipersentasikan adalah $12,4 \%$ diketahui bahwa besarnya pengaruh media pembelajaran terhadap minat belajar siswa sebesar $12,4 \%$ sedangkan $87,6 \%$ dipengaruhi oleh faktor-faktor lain yang tidak dijelaskan dalam penelitian ini.

Hasil penelitian ini memberikan beberapa informasi, yaitu: 1) Media pembelajaran memberikan pengaruh positif dan signifikan terhadap minat belajar siswa; 2) Salah satu cara untuk meningkatkan minat belajar siswa adalah melalui peningkatan media pembelajaran dan 3) Temuan ini memberikan penegasan terhadap teori minat belajar yang menyebutkan bahwa minat belajar dipengaruhi oleh berbagai faktor yang salah satunya adalah media pembelajaran. 


\section{Pengaruh Komunikasi Interpersonal Gurur terhadap Minat Belajar Siswa}

Pengujian hipotesis yang dilakukan bertujuan untuk membuat suatu kesimpulan bahwa Variabel Komunikasi Interpersonal Guru memiliki pengaruh positif terhadap Variabel Minat Belajar Siswa di SMKN 1 Bandung. Berdasarkan perhitungan hipotesis dari pengolahan data di SPSS 20.0 maka diperoleh $t_{\text {hitung }} \geq t_{\text {tabel }}$ dengan nilai 4,100 > 1,98397, yang dimana $\mathrm{H}_{0}$ ditolak dan $\mathrm{H}_{1}$ diterima. Dengan kesimpulan bahwa "Terdapat pengaruh positif antara Komunikasi Interpersonal Guru dengan Minat Belajar Siswa pada Mata Pelajaran Kearsipan di SMKN 1 Bandung ".

Persamaan regresi linier sederhana untuk hipotesis Variabel Komunikasi Interpersonal Guru $\left(\mathrm{X}_{2}\right)$ terhadap Variabel Minat Belajar Siswa $(\mathrm{Y})$ adalah $\hat{\mathrm{Y}}=27,389$ $+0,582(\mathrm{X})$. Tanda positif (+) menunjukkan hubungan antara variabel bebas dengan variabel terikat berjalan satu arah, yang artinya setiap peningkatan atau penurunan di satu level variabel, akan diikuti oleh peningkatan atau penurunan di satu variabel lainnya, sehingga apabila semakin tinggi tingkat komunikasi interpersonal guru maka semakin tinggi minat belajar siswa, begitupun sebaliknya.

Hasil nilai perhitungan korelasi yang didapat sebesar 0,378 , ini berarti nilai korelasi tersebut berada pada 0,200 sampai 0,399 dan berada pada kategori lemah. Hal tersebut mengindikasikan bahwa adanya pengaruh yang lemah dari Variabel Komunikasi Interpersonal Guru $\left(\mathrm{X}_{2}\right)$ dan Variabel Minat Belajar Siswa (Y).

Dari perhitungan koefisien determinasi di atas, dapat dilihat bahwa koefisien determinasi (R Square/ $\mathrm{r}^{2}$ ) sebesar 0,143 atau jika diprosentasekan adalah 14,3\% diketahui bahwa besarnya pengaruh komunikasi interpersonal guru terhadap minat belajar siswa sebesar $14,3 \%$ sedangkan $85,7 \%$ dipengaruhi oleh faktor-faktor lain yang tidak diteliti dalam penelitian ini.

Hasil penelitian ini memberikan beberapa informasi, yaitu: 1) Komunikasi interpersonal guru memberikan pengaruh positif dan signifikan terhadap minat belajar siswa; 2) Salah satu cara untuk meningkatkan minat belajar siswa adalah melalui peningkatan komunikasi interpersonal guru dengan siswa dan 3) Temuan ini memberikan penegasan terhadap teori minat belajar yang menyebutkan bahwa minat belajar dipengaruhi oleh berbagai faktor yang salah satunya adalah komunikasi interpersonal guru.

\section{Pengaruh Media Pembelajaran dan Komunikasi Interpersonal terhadap Minat Belajar Siswa}

Pengujian hipotesis yang dilakukan bertujuan untuk membuat suatu kesimpulan bahwa Variabel Media Pembelajaran dan Komunikasi Interpersonal Guru memiliki pengaruh positif terhadap Variabel Minat Belajar Siswa di SMKN 1 Bandung.

Berdasarkan perhitungan hipotesis regresi ganda dari pengolahan data di SPSS 20.0 maka diperoleh $\mathrm{F}_{\text {hitung }} \geq \mathrm{F}_{\text {tabel }}$ dengan nilai 13,309>3,09, yang dimana $\mathrm{H}_{0}$ ditolak dan $\mathrm{H}_{1}$ diterima. Dengan kesimpulan bahwa "Terdapat pengaruh positif antara Media Pembelajaran dan Komunikasi Interpersonal Guru terhadap Minat Belajar Siswa pada Mata Pelajaran Kearsipan di SMKN 1 Bandung”.

Angka konstan dari unstandarized coefficients sebesar 16,235. Artinya jika tidak ada Media Pembelajaran $\left(\mathrm{X}_{1}\right)$ dan Komunikasi Interpersonal Guru $\left(\mathrm{X}_{2}\right)$, maka nilai konsisten Minat Belajar Siswa (Y) adalah sebesar 16,235. Angka 0,382 mengandung arti bahwa setiap penambahan $1 \%$ tingkat Media Pembelajaran $\left(\mathrm{X}_{1}\right)$, maka Minat Belajar Siswa (Y) akan meningkat sebesar 0,382. Angka koefisien regresi. Nilainya 
sebesar 0,471. Angka ini mengandung arti bahwa setiap penambahan $1 \%$ tingkat Komunikasi Interpersonal Guru $\left(\mathrm{X}_{2}\right)$, maka Minat Belajar Siswa $(\mathrm{Y})$ akan meningkat sebesar 0,471.

Persamaan regresi ganda untuk hipotesis pengaruh media pembelajaran dan komunikasi interpersonal guru terhadap minat belajar siswa adalah $\hat{Y}=16,235+$ $0,382\left(\mathrm{X}_{1}\right)+0,471\left(\mathrm{X}_{2}\right)$. Tanda positif $(+)$ menunjukkan hubungan antara variabel bebas dengan variabel terikat berjalan satu arah, yang artinya setiap peningkatan atau penurunan di satu level variabel, akan diikuti oleh peningkatan atau penurunan di satu variabel lainnya, sehingga apabila semakin tinggi tingkat media pembelajaran dan komunikasi interpersonal guru maka semakin tinggi pula minat belajar siswa, begitupun sebaliknya.

Dari perhitungan koefisien determinasi di atas, dapat dilihat bahwa koefisien determinasi (R Square/ $\mathrm{r}^{2}$ ) sebesar 0,210 atau jika diprosentasekan adalah $21 \%$ diketahui bahwa besarnya pengaruh media pembelajaran dan komunikasi interpersonal guru sebesar $21 \%$ sedangkan $79 \%$ dipengaruhi oleh faktor-faktor lain yang tidak diteliti dalam penelitian ini.

Hasil penelitian ini memberikan beberapa informasi, yaitu: 1) Media pembelajaran dan komunikasi interpersonal guru memberikan pengaruh positif dan signifikan terhadap minat belajar siswa; 2) Salah satu cara untuk meningkatkan minat belajar siswa adalah melalui peningkatan media pembelajaran dan komunikasi interpersonal guru dengan siswa dan 3) Temuan ini memberikan penegasan terhadap teori minat belajar yang menyebutkan bahwa minat belajar dipengaruhi oleh berbagai faktor yang salah satunya adalah media pembelajaran dan komunikasi interpersonal guru.

\section{KESIMPULAN}

Media pembelajaran berada pada kategori tinggi. Indikator kebermanfaatan berada pada kategori tinggi dan indikator terendah adalah Ketersediaan, Komunikasi interpersonal guru yang terdiri dari keterbukaan; empati; sikap mendukung; sikap positif; dan kesetaraan berada pada kategori sedang. Indikator sikap positif berada pada kategori tinggi dan indikator terendah adalah kesetaraan. Minat belajar siswa yang terdiri dari kesukaan; ketertarikan; perhatian; dan keterlibatan berada pada kategori tinggi.

Media pembelajaran berpengaruh positif dan signifikan terhadap minat belajar siswa dan komunikasi interpersonal berpengaruh positif dan signifikan terhadap minat belajar siswa. Media pembelajaran dan komunikasi interpersonal guru berpengaruh positif terhadap minat belajar siswa. Dengan demikian apabila semakin tinggi media pembelajaran dan komunikasi interpersonal guru, maka semakin tinggi minat belajar siswa, begitupun sebaliknya.

\section{DAFTAR PUSTAKA}

Arikunto, S. (2002). Prosedur Penelitian Suatu Pendekatan Praktik. Jakarta: Rineka Cipta.

Arsyad, A. (2009). Media Pembelajaran. Jakarta: PT. Raja Grafindo Persada.

Aw, S. (2011). Komunikasi Interpersonal. Yogyakarta: Graha Ilmu. 
Dalyono, M. (2009). Psikologi Pendidikan. Jakarta: Rineka Cipta.

Djamarah, S. (2011). Psikologi Belajar. Jakarta: Rineka Cipta.

Hamalik, O. (2009). Proses Belajar Mengajar. Jakarta: PT. Bumi Aksara.

Herlina. (2010). Minat Belajar. Jakarta: Bumi Aksara.

Miarso, Y. H. (2004). Menyemai Benih Teknologi Pendidikan. Jakarta: Kencana Prenada Media.

Muhidin, S. A., \& Sontani, U. T. (2011). Desain Penelitian Kuantitatif. Bandung: Karya Andhika Utama.

Mulyana, D. (2009). Ilmu Komunikasi Suatu Pengantar. Bandung: Rosda.

Nazir, M. (2005). Metode Penelitian. Bogor: Ghalia Indonesia.

Nurmala. (2012). Faktor-faktor Yang Mempengaruhi Minat Siswa Untuk Melanjutkan Ke Sekolah Menengah Kejuruan. Jurnal Kependidikan, Volume 42, Nomor 2, 162-172.

Slameto. (2015). Belajar dan Faktor-faktor Yang Mempengaruhinya Edisi Revisi. Jakarta: Rineka Cipta.

Sudjana, N. \& Rivai, A. (2009). Media Pengajaran. Bandung: Sinar Baru Aglesindo.

Schiefele, U. (1991). Interest, Learning adn Motivation. First Published in Educational Psychologist, 299-323.

Syah, M. (2013). Psikologi Belajar. Jakarta: PT. Raja Grafindo Persada.

U-Je Lee, d. (2011 Global Journal of Engineering Education). The Influences of Interest Learning and Learning Hours on Learning Outcomes of Vocational College Students in Taiwan: Using a Teacher's Instructional Attitude As Ahe Moderator. Volume 13, Number 3, 41.

Warsita, B. (2008). Teknologi Pembelajaran Landasan dan Aplikasinya. Jakarta: Rineka Cipta.

Winkel, W. S. (2007). Psikologi Pengajaran. Jakarta: PT. Gramedia. 